\section{Drama in the Galapagos}

The past three years have been full of incident in the Galapagos Islands. The most recent issue of noticias de Galapagos reported it as an 'ordeal by fire and water'. The torrential rains and warm seas of the $1983 \mathrm{El}$ Niño disrupted breeding and endangered some populations of endemic species as well as scientific and conservation projects. A drought followed in 1984 and this contributed to the difficulty of fighting the fire in the Charles Darwin Research Station. As 1985 began, the Research Station was being restored, thanks to the generosity of its supporters, and many, though not all, of the species adversely affected by $\mathrm{E}$ Niño were recovering.

Then, on 26 February 1985, a fire broke out on Isabela Island, the largest in the archipelago. Started accidentally by farmers at Santo Tomas burning diseased coffee bushes, it spread into the National Park. The fire bumed long and intensely, fuelled by the abnormally heavy growth of vegetation induced by the El Niño rains and dried by the 1984 drought. Ecuador mobilized 300 soldiers and 140 local residents to dig a 50 $\mathrm{km}$ trench to halt its spread. In March it appealed for international aid. Canada responded by sending two flying boats, which bombed the critical areas with tons of seawater; the US sent troops and fire-fighting experts. In April, these combined efforts, helped by the first real rain for many months, brought the fire under control, although it was not completely extinguished since up to $2 \mathrm{~m}$ depth of ancient humus and roots continued to provide fuel.

While the fire raged, there were fears for human life and for wildlife, particularly for the Sierra Negra race of giant tortoises whose habitat was in the fire's path. Fortunately, the fire was controlled before it became necessary to put into effect the airlift rescue operation for some of the tortoises. The fire destroyed perhaps a total of 40,000 ha (99,000 acres) of scrub and grassland, about onequarter of the vegetated parts of the Island. Much of this was used for cattle grazing, a small part for human settlement and a smaller fraction was in the officially protected area. It is difficult to predict the long-term effects of the destruction of many small birds, reptiles, insects and plants. Although Editorial the native wildlife of these volcanic islands is fireadapted, this fire was unusually severe.

The fire is out and the drama is over. However, the less newsworthy, but more important threats to the Galapagos ecosystem remain: tourism and invasion by alien species. Some Ecuadorean politicians would like to see large-scale recreation-type tourism developed in the Islands as a revenue booster. In response to a resolution passed at last year's IUCN General Assembly in Madrid, calling on Ecuador to quash any such development, Ecuador's President responded by promising that his Government would do all it could to preserve the natural balance of the Island's ecosystems and protect them from harmful human influences. Invasion by alien species, the other major threat, may have been exacerbated by the fire-fighting activities themselves, necessary as they were. There are fears that the trenches that were dug may now serve as roads into the previously almost inaccessible hinterland. The mass human invasion that occurred during the fire-fighting may already have introduced foreign species. Under normal conditions, scientists and park wardens take the precaution of disinfecting clothes, equipment and food to prevent the introduction of alien organisms into the more strictly protected areas of the Park.

Galapagos is a World Heritage Site, and funds have been pledged from UNESCO to help rehabilitate the officially protected areas affected by the fire; financial support is also available from concerned conservation groups for habitat restoration. The settlers, who lost homes, crops and cattle, also need help. Although settlement in the Galapagos is a contentious issue, the farmers are there to stay and the Ecuadorean Government is concerned to make settlement compatible with nature protection in the Islands. In this context, starting afresh on Isabela is an opportunity not to be missed. The long-term prospects for keeping the Islands in good ecological shape depend on keeping tourism and settlement within sensible limits. It is very difficult to attract funds to attain conservation objectives by indirect means, but it would be gratifying if international funds were made available to help Ecuador in this task. 